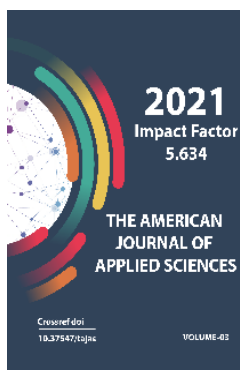

\title{
Parent Problem How To Solve Causes Of Child Conflict In The Family
}

Iroda Rasulova

Lecturer, Shakhrisabz Branch Of Tashkent State Pedagogical University Named After Nizami, Uzbekistan

Journal Website:

http://usajournalshub.c om/index,php/tajas

Copyright: Original content from this work may be used under the terms of the creative commons attributes 4.0 licence.

\section{ABSTRACT}

This article discusses the main goal is to socialize the child, that is, the parents instill in the child the values and behaviors that are appropriate for a member of society. If the child resists attempts to change the behavior of the parents, this process of socialization often leads to conflicts, which is a fact of conflict between parents and children. First of all, disagreement between parent and child is an inevitable reality.

\section{KEYWORDS}

Child, parents, conflicts, member of society, disagreement, inevitable reality situation, clothing choice, sleep patterns

\section{INTRODUCTION}

Parent-child conflict is a situation in which parents and children are confronted with each other. Sources of conflict between parents and children range from relatively insignificant issues, such as clothing choice or sleep patterns, to very serious issues related to a child's safety and well-being. The main goal is to socialize the child, that is, the parents instill 
in the child the values and behaviors that are appropriate for a member of society. If the child resists attempts to change the behavior of the parents, this process of socialization often leads to conflicts, which is a fact of conflict between parents and children. First of all, disagreement between parent and child is an inevitable reality. Parents cannot engage in the process of socialization without encountering their reluctant children from time to time, and children do not have to test the limits of their autonomy from time to time without offending their parents.

\section{THE MAIN FINDINGS AND RESULTS}

Conflict occurs when family members have different views or beliefs that contradict each other. A peaceful solution is measured by respect for the negotiations and the other person's point of view.

As a result of research we have the following recommendations:

$>$ If you think you need help, seek professional advice $\neg$

$>$ Once both parties understand each other's point of view and feelings, you decide together.

$>$ Suggestions:

$>$ Ruining to find as many solutions as possible.

$>$ Be prepared to compromise.

$>$ Make sure everyone clearly understands the chosen solution;

$>$ Adherence to the decision after it is made;

$>$ Write it as a "contract" if necessary;

$>$ Conflict is exacerbated when participants are too angry to listen to each other. Misunderstandings reinforce arguments.

$>$ Suggestions include:
Try to keep yourself calm.

$>$ Trying to put emotions aside.

$>$ Do not interrupt the other person while speaking.

$>$ Actively listen to what they have to say and what they mean.

$>$ Check that you understand them by asking questions.

$>$ Communicate the side of the story clearly and sincerely.

Resist the urge to raise other unresolved but unrelated issues.

Usually, our first annoying motivation is to emphasize that we are right and win the debate at any cost. When both sides stubbornly cling to their weapons, a peaceloving resolution can be difficult, if not impossible, to find. It helps if everyone in a family decides to listen to each other and negotiate instead.

If the problem needs to be tackled, it needs to be developed. You have to try to separate it from the person. If you are overly angry at talking quietly, it is recommended that you try to cool down first. It is important to keep in mind that the idea is to resolve the dispute, not to win the debate.

The other person's point of view is respected through attention and listening. It is necessary to speak clearly and rationally, to try to find common ground. It is well known that certain stages of the family lead to conflict. This includes:

Each of these stages brings new and different stresses and potential conflicts. A change in the situation in the family can also harm the family and lead to conflicts. This includes the following activities: 
The American Journal of Applied sciences

(ISSN - 2689-0992)

Published: April 30, 2021 | Pages: 329-333

$>$ Divorce or divorce

$>$ Moving to a new home or country

$>$ Long-distance travel to work

$>$ Switching for interstate work.

$>$ Changes in financial conditions.

Every parent's thoughts, values, and needs also change, and they no longer fit them.

Conflict can occur when family members have different views or beliefs that contradict each other. Sometimes conflict can arise when people misunderstand each other and come to the wrong conclusion. Conflicts that cannot be resolved peacefully can lead to quarrels and protests.

It is common to disagree with each other from time to time. Occasional conflict is part of family life. However, ongoing conflict can lead to stress and damage relationships. Some people find it difficult to control their emotions and become intentionally upset, aggressive, or even violent.

Communicating in a positive way helps reduce conflicts so that family members can resolve them peacefully. This usually means agreeing or disagreeing with all compromises.

Sometimes, it is difficult to overcome the strong emotions or power imbalances that can occur in a relationship, and they can only be resolved through counseling.

Of course, the money is huge. From fighting for inheritance to disagreeing over who should pay for elderly parents or family events, when it comes to why families are quarreling, family tops the list of financial conflicts. If family members feel they have been treated unfairly or have not been given their due share, they may become angry for years, perhaps even a lifetime. This is because money is often associated with meanings and emotions that have a profound effect on individuals. They may feel cheated, disrespected, or have had a significant impact on their entire lifestyle as a result of these financial conflicts. Such associations and the resulting painful feelings are not easily forgotten. So a family struggling for money can be very destructive and why this type of issue needs to be resolved and resolved as quickly as possible.

Several families run a family business, often started by a single married couple and then handed over to the couple's children, who have to find ways to work together. Brothers and sisters also tend to do business together. It's hard to trust people today, and we have to trust our brothers, don't we? Unfortunately, there are all sorts of contradictions in family business. Partnership is difficult, whether the partners are cousins or not. But when partners are family members, business conflicts often turn into big family conflicts. Without investment, brothers can be put to the test; cousins can intensify hostility towards each other; even elderly parents can be brought in to take the side of sibling business partners.

\section{CONCLUSION}

Conflict due to family events

Events are stressful without causing interference without any interpersonal problems. Planning takes work, money, and time, and when things don't go as planned, it can lead to a lot of worries. Perhaps eventrelated stress is one of the most common causes of interpersonal problems, and of course, interpersonal problems exacerbate stress. Families are often on topics related to 
big and even small events, for example: who is on the guest list (and who is out), who pays for what, which dates work for everyone, as the venue of the event topics are often debated. and who to use as a salesperson. Everyone involved considers their needs to be their top priority ... which makes it very difficult to resolve family disputes about events.

As parents get older, siblings are usually responsible for how they care for their aging parents. Some people feel that the best place for their parents would be in one of the orphanages or an orphanage, while others think they should stay in a family home or retirement community. There is no easy answer to what to do about caring for elderly parents, so a fraternal conflict to care for an elderly parent is a responsibility for siblings and relatives for the elderly. can intensify stubbornness and deep anger among other parties.

Adopting a stepchild is a serious and emotional act; but adopting a stepparent is probably more serious and difficult. Obviously, when underage children live in a family with a stepparent whom they dislike and / or dislike, the family unit is prepared for strife and anger. Even older children of a remarried parent may face conflict with their parent's choice of a new partner. And when children, especially young children, are affected, other members of the family may be involved in the conflict between the stepparent and the stepchild. If the problems are obvious and getting worse, grandparents, uncles and aunts can drop two cents, which can lead to conflicts between them and the new stepfather or even the biological parent. Of any type of family conflict, it can be the most difficult to witness a conflict between a stepparent and a stepchild, as this can directly involve young children. .

Divorced parents are causing conflicts over the care and upbringing of their children

Of course, there can be (and are) completely separate articles on the subject of divorce proceedings. Putting financial issues aside for a moment, the proper care and upbringing of children in general is a major controversy for many divorcees. One parent may have a harder style, for example, the other is softer. Then every parent feels that as soon as the child leaves to go to the other parent's house, many of their efforts are dissipated. This can be irritating and sometimes irritating. It is a pleasure to see parents working together. Parents who are constantly arguing face a lot of stress due to a conflict with their ex-spouse. Sometimes it is better for ex-partners to simply not communicate, or at least communicate as little as possible, and only then talk about very logistical issues related to the child (i.e. schedule, excursions, etc.).

Get help on all types of family conflicts

There is no easy solution to any type of family conflict. Sometimes, a motivated family member can be responsible in handling family disputes to resolve family disputes and help all parties get through the problems. However, often families may not be able to resolve the conflict on their own. Once internal efforts have failed, it makes sense to engage a family conflict resolution strategy specialist to effectively manage all types of family conflicts.

\section{CONCLUSION}

In conclusion, the second and perhaps surprising truth about parent-child conflicts is 
that it doesn't have to be a negative situation. Although we often think that conflict should be avoided, there is growing evidence that it can serve as a drastic catalyst for children's social cognitive development. forces them to take (in order to clearly understand what offends them). situation), to develop evolving negotiation skills, to understand moral and social values, and to effectively reconstruct their feelings in order not to escalate conflicts.

\section{REFERENCES}

1. G'oziyev E.G. Psixologiya(Yosh davrlari psixologiyasi). T., O`qituvchi, 1994.

2. Davletshin M.G., Do`stmuxamedova Sh.A., To`ychiyeva S.M., Mavlonov M. Yosh davrlari va pedagogik psixologiya. T.: TDPU, $2004 \mathrm{y}$.

3. Davletshin M.G. Zamonaviy maktab o'qituvchisi psixologiyasi. Toshkent, 1998.

4. Shcherbakov A.I. Yosh psixologiyasi va pedagogik psixologiyadan praktikum. Toshkent, 1991. 